of the Sāstra text: he was inclined to recognize indications connecting the text with Bihar or Central India.

Suggested by criticism of writings by other scholars were Johnston's brief paper on the Vardhamāna symbol (JRAS., 1932), a topic originally mooted by himself, and his long, and largely controversial, discussion (1939, pp. 217-240) of "Demetrias in Sind". His last papers were a note on "Bird-names in the Indian dialects" (BSOS., viii, pp. 599-601), that on "The Tridandamäla of Aśvaghosan" (JBORS., 1939, pp. 11-14), and his "Ctesias on Indian Manna" (JRAS., 1942).

From about 1931 Johnston frequently contributed to this Journal reviews, which ranged widely over the fields of Sanskrit literature and philosophy, as well as of Pali and Tibetan. He never failed, despite the brevity now usual, to manifest by definite comments or criticisms a serious examination of the matter reviewed.

Johnston's household of three sons and three daughters included children of his brother, predeceased. Upon the outbreak of the war Mrs. Johnston and most of the family left, like so many Oxford families, to reside in America, while Johnston himself took up the life of an " unmarried don" in Balliol College. From the outset of hostilities he rendered full service as an Air Raid Warden and Home Guard. The sympathy of the Society, which he joined as long ago as 1909, becoming a member of its Council in 1935, will go out to his widow and family.

November, 1942.

F. W. Thomas.

\title{
Caroline Augusta Foley Rhys Davids
}

(27тh September, 1857-26Th June, 1942)

With the passing of Mrs. Rhys Davids closes the pioneer stage of Pali studies and of a scholarly interpretation of Pali Buddhism in England. In this capacity she was the co-worker and successor of her husband T. W. Rhys Davids to whom she owed her inspiration for Buddhist studies. His life-work, the editing of the Pali Canon through the medium of the Pali Text Society, she almost concluded.

This enthusiastic missionary of "Gotama the Man" has left us with an abundance of published research which shows a mind gifted with grace and talent, a power of assimilation and an imagination able to lend new life to dead bones and to reinterpret old creeds 
according to new needs. It is not too much to say that the ideas of the educated layman about Pali Buddhism to-day are those first put forth by Mrs. Rhys Davids, and her own translations are worthy of being classed among gems of English poetical literature.

It is impossible to give here more than the barest outline of her work. To whatever journal, dealing with Eastern philosophy and religion, the student may turn, he will find contributions vital with her character, personal as well as scholarly. Since she was not a follower of any particular school of thought but made a school herself, it is not to be wondered that in many of her theories she stood alone. How much of her Buddhism will live, only time can tell. Her hypotheses, supported by an extensive study of Indian philosophy, were truths to her, especially the ideas put forth in her latest stage, like the idea of " becoming ", in which a psychologist might be tempted to see a reflection of her own becoming. Whether correct or not these ideas have proved and will continue to prove an invaluable stimulus to further research. Of her work and its effect we can just say with Horace Exegi monumentum aere perennius.

W. StedE. 